\title{
PENGEMBANGAN ASPEK PARIWISATA SUMBEREJO MELALUI PEMBUATAN DAN PELATIHAN VIDEO PROFIL
}

\author{
Nanda Harda Pratama Meiji ${ }^{\star}$, Ridwan Tajul Fahmi, Joan Hesti Gita Purwasih, Ahmad Arif \\ Widianto \\ nanda.harda.fis@um.ac.id
}

Jurusan Sosiologi, Fakultas Ilmu Sosial, Universitas Negeri Malang

Diterima 28 November 2020, dipublikasikan 30 April 2021

\begin{abstract}
Abstrak
Pengabdian ini dilakukan di Desa Sumberejo yang terletak di ujung selatan Jember. Dua pantai indah berpasir hitam yang diapit 3 bukit menjadi daya Tarik utama Desa Sumberejo. Memiliki daerah persawahan yang luas dan hasil laut yang besar menjadi penambah potensi desa tersebut. Namun potensi yang ada belum dirasakan secara maksimal oleh masyarakat Desa Sumberejo. Tidak tereskposnya keindahan pantai dan bukit membuat pengunjung yang datang hanya dari kawasan Jember sendiri. Diperlukan penyelesaian masalah berupa pemanfaatan media promosi dan branding desa. Pengabdian masyarakat ini berfokus pada pengembangan potensi yang dimiliki Desa Sumberejo melalui video profil desa dan pelatihan masyarakat pada pembuatan video profil desa. Media video dipilih karena mudah dipublikasikan di berbagai macam platform dan mudah menarik minat masyakat. Media video saat ini tengah mengalami tren yang besar di masyarakat, oleh sebab itu video dipilih menjadi media yang tepat untuk mengenalkan potensi yang dimiliki Desa Sumberejo pada khalayak umum. Keterlibatan masyarakat dalam setiap prosesnya sangat diperhatikan dan dimaksimalkan agar masyarakat tidak teraleniasi dengan perkembangan teknologi media yang hendak digunakan. Tidak hanya membuat, dalam pengabdian ini pemuda desa juga diberikan pengetahuan dan keterampilan dalam pembuatan video. Hal ini dilakukan agar kedepannya mereka mampu membuat video yang menarik untuk mengembangkan potensi desanya.
\end{abstract}

Kata Kunci: Video Profil, Pariwisata Sumberejo, Pengembangan Pariwisata

\section{PENDAHULUAN}

Dewasa ini, konteks pemberdayaan masyarakat jauh lebih berkembang daripada periodeperiode sebelumnya. Proses pemberdayaan bukan hanya sekedar menjabarkan bagaimana komunitas bertindak mengubah dirinya tetapi lebih dari itu, yakni bagaimana melakukan branding guna peningkatan kapabilitas di masyarakat (Hanjani \& Wulaningrum, 2019; Muniz \& O'Guinn, 2001; Supina, S.ST Par, 2012). Maka tidak heran apabila kemudian program pemberdayaan juga membutuhkan pencitraan guna meningkatkan popularitas pemberdayaan masyarakat di kalangan publik.

Selama ini beberapa penelitian maupun pemberdayaan masyarakat terkait teknologi yang dilakukan berkutat pada konteks SID (Sistem Informasi Desa) (Lestari, Tabrani, \& Ayumida, 2018; Melinda, Borman, \& Susanto, 2018). Kerumitan pembuatan SID membuat pemerintah desa terfokus pada pembuatan SID. Sementara itu sebenarnya salah satu hal yang dibutuhkan dalam proses SID adalah pembuatan video Profil Desa yang mumpuni guna mengenalkan desa. Hal ini karena selama ini branding mengenai desa itu sendiri masih belum terlalu dikenal, apalagi bagi desa-desa yang memang kurang populer. Permasalahan yang kemudian muncul adalah bagaimana kompetensi Sumber Daya Manusia (SDM) di masing-masing desa biasanya masih belum mampu membuat dan mempromosikan desanya secara baik. Terlebih mengingat di era modernitas lanjut seperti saat ini dimana arus informasi berkembang pesat dan berlipat ganda setiap saat. Seringkali masyarakat hanya menerima arus informasi dari luar (nasional maupun global) secara masif namun informasi mengenai desa justru lambat dan tidak terdokumentasikan dengan baik. Pembuatan video profil desa ini diharapkan dapat mempercepat arus informasi tentang desa, serta dapat semakin mudah diperoleh oleh orang luar secara baik dan menarik. 
Salah satu desa yang memiliki permasalahan tersebut yakni Desa Sumberejo, Kecamatan Ambulu, Kabupaten Jember. Wilayah yang terdiri dari 6 dusun ini rupanya juga kebingungan ketika mereka harus memberikan informasi mengenai desa mereka pada masyarakat Desa Sumberejo khususnya kepada masyarakat luas secara nasional secara umum. Memiliki berbagai keunggulan pada sektor-sektor seperti pertanian, perkebunan, dan pariwisata rupanya justru tidak terdokumentasikan dengan baik. Alhasil sektor-sektor tersebut agak meredup seiring dengan nama Desa Sumberejo itu sendiri. Oleh sebab itu diperlukan upaya branding yang lebih maksimum yang diawali dengan proses internetisasi data desa melalui video Profil Desa. Harapannya adalah melalui pembuatan dan pelatihan pembuatan video profil desa di Desa Sumberejo ini dapat memberikan manfaat bagi peningkatan branding desa serta komponen-komponen potensial yang ada di dalamnya. Diperlukan kerjasama bukan hanya dari tim pemberdayaan semata namun partisipasi aktif masyarakat Desa Sumberejo sebagaimana poin inti dalam proses community development (Ife \& Tesoriero, 2008).

\section{METODE}

Berdasarkan penelaahan awal sebelum pengabdian ini dilakukan, terdapat beberapa rencana yang akan diselenggarakan saat pengabdian ini nantinya dilakukan. Melalui penelaahan awal didapatkan 2 permasalahan utama di desa Sumberejo, Kabupaten Jember yakni manajemen dan pemasaran potensi desa yang dimiliki. Permasalahan tersebut terutama terkait bagaimana meningkatkan partisipasi warga Desa Sumberejo dalam upaya optimalisasi potensi desa. Selain itu pemasaran dan branding Desa Sumberejo masih dapat dibilang lemah terutama di era digital seperti saat ini dimana dunia seakan berlari menuju digitalisasi produk (Mendick, 2015).

Oleh karena itu diperlukan beberapa kegiatan yang melibatkan partisipasi warga desa Sumberejo guna menekankan solusi atas permasalahan manajemen dan pemasaran yang ada yakni observasi, sosialisasi, pelatihan, dan launching Video Profil. Observasi dilakukan untuk memantapkan dan melihat potensi pariwisata desa yang ada di wilayah Desa Sumberejo. Sosialisasi kemudian dilakukan untuk memperkenalkan model yang akan digunakan untuk melakukan digitalisasi dan penguatan branding Desa Sumberejo. Setelah itu dilakukan pelatihan pada para stakeholder desa Sumberejo terkait digitalisasi dan branding potensi Desa Sumberejo. Terakhir adalah launching profil Desa Sumberejo yang merupakan hasil kegiatan bersama. Adapun luaran untuk pengabdian kali ini yakni video potensi Desa Sumberejo.

Tahapan kerja yang dilaksanakan dalam pengabdian di Desa Sumberejo terbagi dalam dua tahapan. Pertama adalah perencanaan, tim melakukan beberapa dikusi internal bersama tim untuk menentukan tujuan dan cara untuk memenuhi tujuan tersebut. Tim mengundang salah satu mahasiswa yang berasal dari desa Sumberejo untuk diajak berdiskusi. Hal ini dimaksudkan untuk mengumpulkan sebanyak mungkin informasi yang kemudian dijadikan bahan pertimbangan pada saat menentukan cara tim dalam memenuhi target yang sudah dicanangkan. Tahap perencanaan ini berlangsung selama satu bulan sebulum berangkat ke Desa Sumberejo.

Setelah kami sudah matang dalam tahapan perencanaan, tim berangkat ke Desa Sumberejo. Tahapan ini kami sebut sebagai tahapan turun lapangan. Turun lapangan kami lakukan secara bertahap, turun lapangan yang pertama melakukan pengenalan. Turun lapangan kedua FGD dengan Pihak desa. Turun lapangan ketiga mengabil bahan untuk video serta pengumpulan gambar untuk website. Turun lapangan yang terakhir adalah penerbitan video dan website. Dalam setiap tahapan turun lapangan kami selalu melibatkan pemuda desa dengan maksud untuk memberikan pelatihan terhadap mereka tentang website dan video.

\section{HASIL DAN PEMBAHASAN}

Video Profil Desa adalah media yang tepat untuk melaksanakan branding desa. Bentuk video Profil Desa lebih dipilih untuk mengoptimalisasi potensi dan branding desa karena format ini yang paling mudah dicerna oleh khalayak umum. Video yang menarik akan dengan mudah membuat orang tertarik tentang Desa Sumberejo dan segala potensi yang ada di dalamnya. Penyampaian informasi dengan video juga merupakan hal yang sudah umum dilakukan di era digital saat ini. Alasan lain pemilihan video yakni karena video merupakan media yang gampang dipublikasikan pada banyak platform digital 
masa kini. Kita dapat dengan mudah mempublikasikan video melalui media sosial, seperti YouTube, Instagram, Facebook, Twitter dan juga Whatsapp. Video tersebut kemudian dapat digunakan untuk menyebarluaskan informasi dan pariwisata yang dapat kita jumpai di Desa Sumberejo.

Video Profil Desa Sumberejo dibuat melalui beberapa tahapan. Tahapan yang pertama adalah melakukan komunikasi dengan semua elemen yang ada di desa. Komunikasi dengan kepala desa, perangkat desa, pemuda dan juga masyarakat desa secara umum untuk mengetahui kebutuhan serta mengkomunikasikan proses pembuatan video Desa Sumberejo. Kebutuhan Desa Sumberejo tentu saja berbeda dengan kebutuhan desa lainnya. Hasil dari tahapan pertama ini didapati bahwa potensi yang harus didorong dan dioptimalkan adalah sektor pariwisatannya. Desa sumberejo memiliki potensi pantai yang indah dan bukit yang sangat menarik. Melalui video profil yang akan dibuat, diharapkan akan semakin banyak wisatawan yang akan datang dan menikmati keindahan alam Desa Sumberejo

Tahapan selanjutnya dalam pembuatan video profil Desa Sumberejo adalah proses pembuatan story line. Setelah mengantongi hal yang menarik selama proses observasi di Desa Sumberejo ditambah dengan keinginan perangkat desa dan jajarannya, tim kemudian menyusun story line. Pembuatan story line dimaksudkan untuk membuat jalannya video semakin menarik dan mencakup semua yang dibutuhkan oleh Desa Sumberejo. Dalam pembuatan story line tim juga membuat bagaimana pariwisata tersebut diangkat dalam video. Dokumentasi kemudian dimulai dari gaya pengambilan gambar, urutan cerita dan juga waktu terbaik objek pariwisata tersebut. Gaya pengambilan gambar yang disepakati pada video profil Desa Sumberejo adalah Cinematic Shoot dengan deskripsi atau narasi berupa Voice Over. Gaya yang seperti ini merupakan trend pengambilan gambar yang menarik dan sangat menonjolkan keindahan visual. Bentuk ini dipilih agar video profil Desa Sumberejo berbeda dengan video profil desa yang pada umumnya digunakan oleh desa lain. Selain itu juga berpotensi membuat orang lain tertarik dengan keindahan wisata Desa Sumberejo. Adapun urutan cerita video profil Desa Sumberejo sebagai berikut.

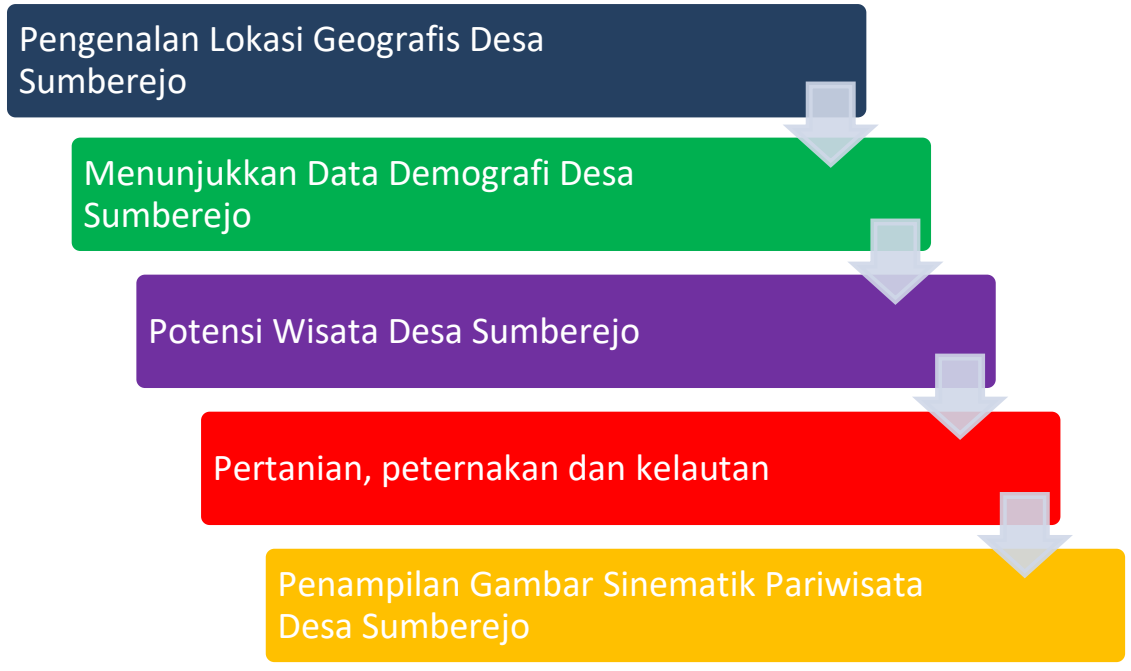

Gambar 1 Urutan Cerita dalam video profil Desa Sumberejo

Tim kemudian menunjukkan hasil video yang telah dibuat kepada masyarakat dan jajaran perangkat Desa Sumberejo. Pemerintah Desa Sumberejo mengapresiasi bentuk video yang dibuat. Dalam sambutannya bapak kepala desa berkata, "video profil yang dibuat oleh tim UM sudah mampu memberikan gambaran umum tentang Desa Sumberejo, dengan adanya video ini saya berharap akan semakin banyaknya orang yang tahu dan tertarik untung datang di des akita ini". Tim kemudian melakukan pelatihan pembuatan video profil desa pada pemuda Desa Sumberejo. Pemuda Desa Sumberejo dipilih menjadi pihak yang dilatih karena beberapa alasan. Pertama, pemuda lebih mudah beradaptasi dengan teknologi baru. Perlu diketahui bahwa dalam pembuatan sebuah video yang menarik, diperlukan tahapan pengambilan gambar dan teknik editing yang baik. Semua proses tersebut memerlukan pemahaman yang lebih pada kamera dan juga software komputer. Untuk itu, pemuda adalah pilihan yang tepat. Kedua, lebih memahami trend yang ada saat ini. Hal ini bermanfaat agar 
video yang dihasilkan kedepannya tidak terkesan ketinggalan jaman dan lebih mudah diterima khalayak umum. Ketiga, memiliki rasa semangat dan keingintahuan yang tinggi. Sifat yang demikian memberikan tim keyakinan bahwa Pemuda Desa Sumberejo dapat menghasilkan video yang menarik di kemudian hari.

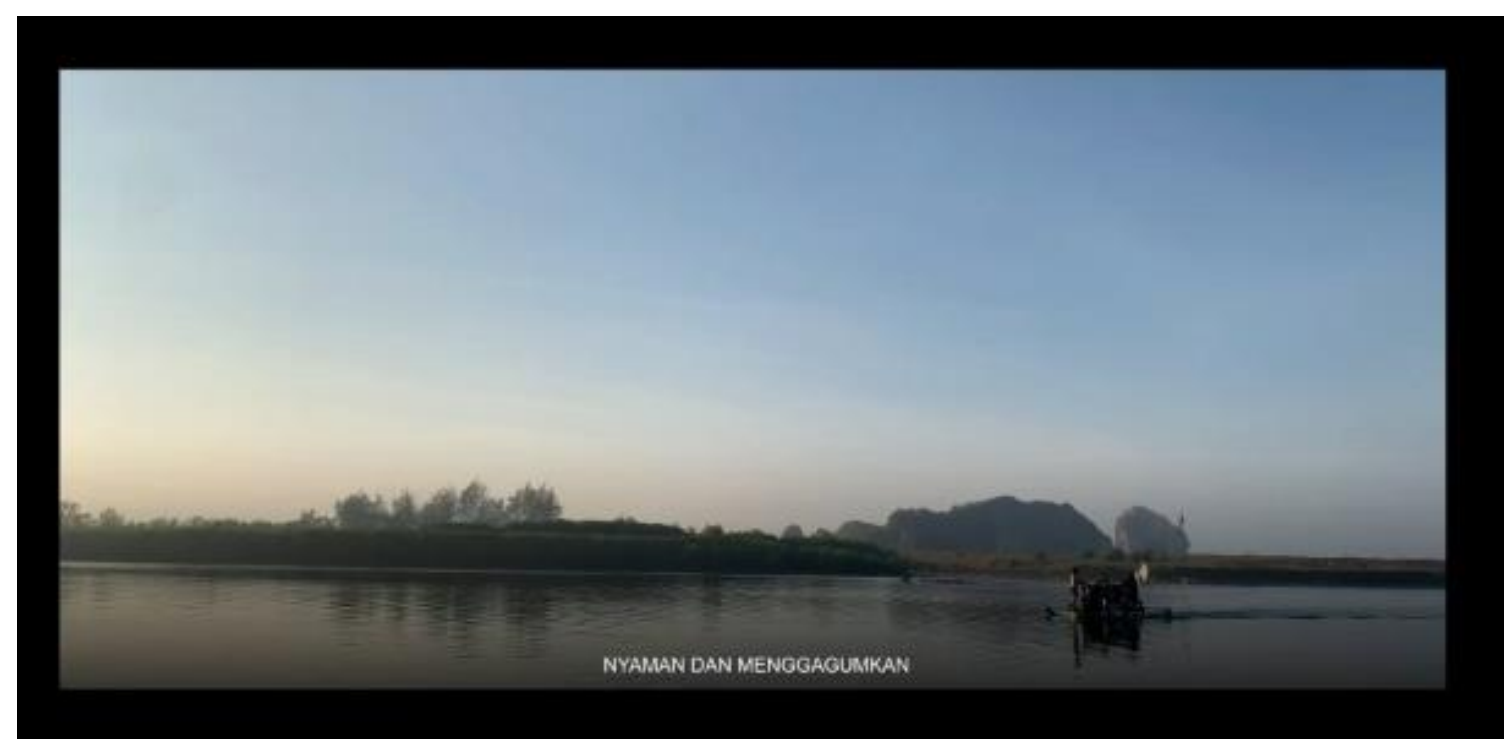

Gambar 2 potongan video profil Desa Sumberejo

Kali ini Analisa terkait pengembangan potensi pariwisata di Sumberejo menggunakan konsep TALC yang diperkenalkan oleh Butler dimana terdapat proses keberlanjutan dalam konteks pariwisata (Baum, 1998; Diedrich \& García-Buades, 2009). Berdasarkan hasil wawancara dan juga observasi yang dilakukan selama beberapa bulan dapat diperhatikan mengapa potensi wisata di wilayah Sumberejo kurang dikenal karena masih berada pada tahapan involvement (terdapat keterlibatan). Sebagaimana dalam penjelasan konsep TALC bahwa pada tahapan tersebut, di wilayah wisata Desa Sumberejo ramai ketika waktu libur tiba (akhir pekan), adanya peran pemerintah desa dan masyarakat lokal untuk ikut meningkatkan fasilitas serta akses lokasi pariwisata, dan adanya beberapa promosi yang dilakukan serta inisiatif untuk mengembangkan potensi wisata (Pantai) di Sumberejo (Suryaningsih \& Suryawan, 2016).

Dari variabel yang digunakan oleh Butler tersebut menunjukkan bahwasanya perlu peningkatan pemberdayaan bagi masyarakat di Kawasan Sumberejo. Sebagaimana dijelaskan dalam konsep pemberdayaan masyarakat bahwa memang dibutuhkan proses yang melibatkan semua pihak (bukan hanya pemerintah desa semata) agar memunculkan kontinuitas (Beard \& Dasgupta, 2007). Dari aspekaspek yang ada memang dapat dilihat beberapa indikator dimana dibutuhkan pembekalan serta pendampingan yang lebih menyeluruh dan berkelanjutan. Adapun aspek-aspek wilayah Sumberejo masuk dalam kategori involvement yakni (berdasarkan hasil observasi lapangan dan wawancara).

1. Wilayah pantai Watu Ulo yang dikoordinir oleh masyarakat lokal, mulai dari tempat parker hingga tiket masuk (keterlibatan masyarakat lokal).

2. Pantai Watu Ulo dan Papuma yang ramai ketika akhir pekan dimana banyak pelancong yang berasal dari wilayah Kota Jember dan juga luar daerah berkunjung menikmati keindahan pantai.

3. Peningkatan jumlah wisatawan lokal yang berada pada kisaran angka 500-600 wisatawan pada akhir pekan. Berbeda pada hari biasa yang hanya sekitar 50-100 orang wisatawan.

4. Terdapat beberapa warung makan dan juga warung kelontong yang menjajakan dagangan dikelola oleh masyarakat yang berada di lingkup pantai.

5. Adanya poster serta beberapa pamflet di area tempat makan sekitar Ambulu yang dikeluarkan oleh pihak desa bekerjasama dengan pengelola wisata lokal untuk menarik wisatawan berkunjung ke objek wisata di Sumberejo.

\section{KESIMPULAN}


Salah satu desa yang mengalami permasalahan tersebut adalah Desa Sumberejo. Dua pantai yang indah diapit dengan tiga bukit menjulang tinggi di bibir pantai merupakan pesona alam yang tak terbantahkan. Ditambah lagi dengan hasil laut yang melimpah dan juga pertanian yang subur membuat Desa Sumberejo seharusnya jadi desa yang memiliki potensi wisata yang sangat besar. Namun semua potensi wisata dan kekayaan alam yang ada tidaklah maksimal jika tidak ada orang yang tau tentang potensi tersebut. Diperlukan penguatan pada sektor promosi dan media branding desa. Hal ini bertujuan agar Desa Sumberejo lebih dikenal oleh masyarakat, baik secara domestik ataupun mancanegara.

Media yang tepat untuk melakukan optimalisasi potensi desa dan branding desa adalah video Profil desa. Video Profil desa adalah media yang tepat untuk melaksanakan branding desa. Bentuk video profil desa lebih dipilih untuk mengoptimalisasi potensi dan branding desa karena format ini yang paling mudah dicerna oleh khalayak umum. Video yang menarik akan dengan mudah membuat orang tertarik tentang apa yang ada di Desa Sumberejo dan segala potensi yang ada di dalamnya. Penyampaian informasi dengan video juga merupakan hal yang sudah umum dilakukan di era digital saat ini. Media video juga sangat mudah untuk di sebarluaskan diberbagai platfrom masa kini.

Dalam pelaksanaan pembuatan video, tim melibatkan partisipasi dari masyarakat. Mulai dari proses perencanaan dan juga pada tahapan penyusunan materi yang akan dimuat dalam video. Melibatkan masyarakat Desa Sumberejo juga dimaksudkan agar kedepannya karya video yang dihasilkan merupakan buah tangan dari masyarakat Desa Sumberejo sendiri. Masyarakat yang aktif dan mandiri untuk mengembangkan desanya adalah point inti yang hendak dicapai dari community development.

Video Profil desa dikemas secara menarik dan berbeda dengan video profil desa biasanya. Menggunakan banyak cinematic shoot dan voice over dengan teknik editing yang mumpuni, membuat video profil Desa Sumberejo menarik dan dapat mengundang rasa penasaran masyarakat. Setelah video berhasil dibuat, giliran tim mengajari pemuda untuk membuat video yang menarik Video yang telah dibuat oleh Tim dari Universitas Negeri Malang adalah awal dari video menarik lainnya yang dibuat oleh pemuda Desa Sumberejo. Harapannya, video yang dihasilkan oleh pemuda Desa Sumberejo dapat bermanfaat bagi masyarakat Desa Sumberejo. Di kemudian hari, Desa Sumberejo mampu memproduksi video branding desa sendiri dan mandiri dalam pengembangan desanya.

\section{UCAPAN TERIMA KASIH}

Kami ucapkan banyak terimakasih pada Bapak Riono Hadi selaku kepala Desa Sumberejo yang senantiasa membantu dalam proses pelaksanaan pengabdian masyarakat yang kami lakukan. Terima kasih juga kami ucapkan pada Universitas Negeri Malang yang memberikan dukungan penuh pada pelaksanaan kegiatan pengabdian masyarakat ini. Tak lupa, kami haturkan terima kasih pada seluruh masyarakat Desa Sumberejo yang telah berperan aktif dalam segala proses pengabdian yang kami lakukan.

\section{DAFTAR PUSTAKA}

Baum, T. (1998). Taking the exit route: Extending the tourism area life cycle model. Current Issues in Tourism. https://doi.org/10.1080/13683509808667837

Beard, V. A., \& Dasgupta, A. (2007). Community Driven Development, Collective Action and Elite Capture in Indonesia. Development and Change.

Diedrich, A., \& García-Buades, E. (2009). Local perceptions of tourism as indicators of destination decline. Tourism Management. https://doi.org/10.1016/j.tourman.2008.10.009

Hanjani, A., \& Wulaningrum, P. D. (2019). Pemberdayaan dan Strategi Marketing Petani Madu Desa Giri Tengah Kecamatan Borobudur-Magelang. ABDIMAS: Jurnal Pengabdian Masyarakat. https://doi.org/10.35568/abdimas.v2i1.261

Ife, J., \& Tesoriero, F. (2008). Community Development: Alternatif Pengembangan Masyarakat di Era Globalisasi. Yogyakarta: Pustak Pelajar.

Lestari, M. A., Tabrani, M., \& Ayumida, S. (2018). Sistem Informasi Pengolahan Data Administrasi Kependudukan Pada Kantor Desa Pucung Karawang. Jurnal Interkom Vol. 13 No. 3.

Melinda, M., Borman, R. I., \& Susanto, E. R. (2018). RANCANG BANGUN SISTEM INFORMASI PUBLIK BERBASIS WEB (STUDI KASUS : DESA DURIAN KECAMATAN PADANG CERMIN 
KABUPATEN PESAWARAN). Jurnal Tekno Kompak. https://doi.org/10.33365/jtk.v11i1.63

Mendick, H. (2015). Youth cultures in the age of global media. Gender and Education (Vol. 27). https://doi.org/10.1080/09540253.2015.1019989

Muniz, A. M., \& O'Guinn, T. C. (2001). Brand Community. Journal of Consumer Research. https://doi.org/10.1086/319618

Supina, S.ST Par, M. P. (2012). PERANCANGAN DESTINATION BRANDING DESA WISATA BERMI KABUPATEN PROBOLINGGO. Universitas Kristen Petra.

Suryaningsih, I. A. A., \& Suryawan, I. B. (2016). POSISI DESA SERANGAN BERDASARKAN ANALISIS TOURISM AREA LIFE CYCLE. JURNAL DESTINASI PARIWISATA. https://doi.org/10.24843/despar.2016.v04.i02.p01 